Research Paper

\title{
Oncogenic STAT5 signaling promotes oxidative stress in chronic myeloid leukemia cells by repressing antioxidant defenses
}

\author{
Jerome Bourgeais ${ }^{1}$, Nicole Ishac ${ }^{1}$, Magdalena Medrzycki ${ }^{2}$, Marie Brachet-Botineau ${ }^{1}$, \\ Laura Desbourdes ${ }^{1}$, Valerie Gouilleux-Gruart', ${ }^{1,3}$ Emmanuel Pecnard ${ }^{1}$, Florence \\ Rouleux-Bonnin ${ }^{1}$, Emmanuel Gyan ${ }^{1,4}$, Jorge Domenech ${ }^{1,5}$, Frederic Mazurier ${ }^{1}$, \\ Richard Moriggl $^{6}$, Kevin D. Bunting ${ }^{2}$, Olivier Herault ${ }^{1,5}$, Fabrice Gouilleux ${ }^{1}$ \\ ${ }^{1}$ CNRS UMR 7292, GICC, Université F Rabelais, Tours, France \\ ${ }^{2}$ Aflac Cancer and Blood Disorders Center of Children's Healthcare of Atlanta and Emory University School of Medicine \\ Atlanta, GA, USA \\ ${ }^{3} \mathrm{CHRU}$ de Tours, Laboratoire d'Immunologie, Tours, France \\ ${ }^{4} \mathrm{CHRU}$ de Tours, Service d'Hématologie Clinique et Thérapie Cellulaire, Tours, France \\ ${ }^{5} \mathrm{CHRU}$ de Tours, Service d'Hématologie Biologique, Tours, France \\ ${ }^{6}$ University of Veterinary Medicine, Medical University of Vienna and Ludwig Boltzmann Institute for Cancer Research, \\ Vienna, Austria \\ Correspondence to: Fabrice Govilleux, email: fabrice.govilleux@univ-tours.fr \\ Keywords: STAT5, Bcr-Abl, chronic myeloid leukemia, oxidative stress, antioxidants \\ Received: May 23, $2016 \quad$ Accepted: July 28, $2016 \quad$ Published: August 22, 2016 \\ Copyright: Bourgeais et al. This is an open-access article distributed under the terms of the Creative Commons Attribution License \\ 3.0 (CC BY 3.0), which permits unrestricted use, distribution, and reproduction in any medium, provided the original author and \\ source are credited.
}

\section{ABSTRACT}

STAT5 transcription factors are frequently activated in hematopoietic neoplasms and are targets of various tyrosine kinase oncogenes. Evidences for a crosstalk between STAT5 and reactive oxygen species (ROS) metabolism have recently emerged but mechanisms involved in STAT5-mediated regulation of ROS still remain elusive. We demonstrate that sustained activation of STAT5 induced by Bcr-Abl in chronic myeloid leukemia (CML) cells promotes ROS production by repressing expression of two antioxidant enzymes, catalase and glutaredoxin-1(GIrx1). Downregulation of catalase and GIrx1 expression was also observed in primary cells from CML patients. Catalase was shown not only to reduce ROS levels but also, to induce quiescence in Bcr-Abl-positive leukemia cells. Furthermore, reduction of STAT5 phosphorylation and upregulation of catalase and GIrx1 were also evidenced in leukemia cells cocultured with bone marrow stromal cells to mimic a leukemic niche. This caused downregulation of ROS levels and enhancement of leukemic cell quiescence. These data support a role of persistent STAT5 signaling in the regulation of ROS production in myeloid leukemias and highlight the repression of antioxidant defenses as an important regulatory mechanism.

\section{INTRODUCTION}

The Signal Transducer and Activator of Transcription factors $5 \mathrm{~A}$ and $5 \mathrm{~B}$ are two closely related STAT family members that play a major role in normal and leukemic hematopoiesis [1]. Both proteins are crucial effectors of cytokine and/or growth factor-induced survival, proliferation and differentiation of hematopoietic cells. Tyrosine phosphorylation is a critical initial step in cytokine-dependent STAT activation and is regulated by JAK family members which bind to cytokine receptors. Phosphorylation of tyrosine residues Y694 (STAT5A) and Y699 (STAT5B) is a prerequisite for dimer formation and transcriptional activation of STAT5-regulated genes [2].

Persistent STAT5 phosphorylation is triggered by tyrosine kinase oncogenes (TKOs) such as Fmslike receptor tyrosine kinase 3 with internal tandem duplications (Flt3-ITD), Kit ${ }^{\mathrm{D} 816 \mathrm{~V}}$, Bcr-Abl and JAK2 ${ }^{\mathrm{V} 617 \mathrm{~F}}$ 
which have been characterized in various myeloid malignancies [3-7]. STAT5 is a crucial downstream effector of Bcr-Abl and JAK2 ${ }^{\mathrm{V} 617 \mathrm{~F}}$, the major transforming agents in Philadelphia-positive $(\mathrm{Ph}+) \mathrm{CML}$ and Philadelphia-negative ( $\mathrm{Ph}-)$ myeloproliferative neoplasms respectively. Inhibition of STAT5 phosphorylation interrupts the transforming potential of these TKOs and the induction of leukemia in mouse models [8-11]. Previous reports indicated that STAT5 is a direct target of these TKOs, but additional events linked to cell transformation are probably involved in STAT5 activation $[12,13]$. It was shown, for instance, that ROS, which are generated in oncogene-transformed cells regulate different redox-sensitive signaling pathways by inducing the reversible oxidation of tyrosine phosphatases, protein kinases and transcription factors $[14,15]$. ROS-dependent inhibition of tyrosine phosphatases might contribute to enhanced tyrosine phosphorylation of signaling proteins including STATs [16, 17]. It is now well recognized that ROS are important initiators and promoters of carcinogenesis and contribute to tumor progression. High levels of ROS promote survival, proliferation, genomic instability and mutagenesis leading to disease progression and drug resistance [18-21]. Oxidative stress is due to an excessive cellular ROS production and/or a deficiency in antioxidant defenses. TKOs were shown to stimulate the production of intracellular ROS in leukemic cells [21-23]. ROS contribute to the regulation of signaling pathways in leukemic cells but elevated levels of ROS may also be dependent on deregulated pathways. Constitutive activation of the PI3-kinase/Akt pathway was shown to increase ROS levels in Bcr-Abl-transformed cells [24]. Bcr-Abl and Flt3-ITD also induce intracellular ROS production through STAT5 signaling $[21,25,26]$. However the mechanisms involved in STAT5-mediated induction of ROS remains unclear. In Flt3-ITD-expressing cells, STAT5 has been proposed to regulate activity of NADPH oxidase, one major cellular source of ROS, via distinct mechanisms [21, 26]. In sharp contrast, it was shown that STAT5A knockdown induced ROS production in $\mathrm{Bcr}_{-} \mathrm{Abl}^{+}$hematopoietic stem/progenitor cells supporting a protective role of STAT5A against oxidative stress in these primary cells [27]. A similar protective effect was observed in pre-B leukemic cells [28]. These controversial data argue for different functions of STAT5 in the regulation of ROS levels, acting either as a repressor or as an inducer through mechanisms that remain unresolved. We show that oncogenic activation of STAT5 induced by Bcr-Abl in CML cells enhances ROS levels through the repression of catalase and glutaredoxin-1 (Glrx1), two enzymes involved in antioxidant defenses. These data suggest that deregulated STAT5 activity directly affects the balance between ROS generation and scavenging to promote oxidative stress in myeloid leukemias.

\section{RESULTS}

\section{STAT5 promotes ROS production in $\mathbf{P h}^{+}$ leukemia cells}

The main aim of this work was to elucidate the mechanisms involved in STAT5-dependent regulation of ROS production in $\mathrm{Bcr}-\mathrm{Abl}^{+}$leukemia cells. Initial experiments were carried out to demonstrate that inhibition of Bcr-Abl kinase activity in KU812 and K562 cell lines resulted in decreased ROS production following treatment with the Bcr-Abl kinase inhibitor: Imatinib Mesylate (IM) (Figure 1). KU812 and K562 cells treated with $1 \mu \mathrm{M}$ IM, a concentration high enough to suppress STAT5 tyrosine phosphorylation (Figure 1A), had a lower level of intracellular ROS compared to nontreated cells as measured using the ROS-sensitive probes H2DCFDA (53\% and 45\% decrease in KU812 and K562 cells respectively) and CellROX (32\% and $12 \%$ decrease) (Figure 1B-1C). To determine whether STAT5 activation is involved in ROS production, we examined the functional consequence of STAT5 inhibition on the regulation of ROS levels in Bcr-Abl ${ }^{+}$cells. Because STAT5 inhibition could indirectly affect ROS levels through induction of apoptosis [29], we performed transient transfections assays to determine, shortly after transfection, the direct effect of STAT5 inhibition on ROS production. In a first set of experiments, KU812, and K562 cells were electroporated with a bicistronic vector allowing expression of a dominant negative Flag-STAT5A $\Delta 749$ mutant $(\triangle 5 \mathrm{~A})$ and a truncated and inactive version of the cell surface expressing CD4 antigen $(\Delta C D 4)$. Cells were next labeled with an APC-conjugated anti-CD4 antibody and the ROS sensitive probe H2DCFDA to determine ROS production in transfected $\triangle \mathrm{CD} 4^{+}$cell populations. ROS levels were decreased in KU812 and K562 cells overexpressing STAT5 $\Delta 749$ when compared to cells transfected with an empty vector (Figure 2A). Expression levels of STAT5A $\Delta 749$ were found similar in KU812 and K562 cells as determined by Western blot analysis (Figure 2B). We then compared the effects of STAT5 knockdown on the regulation of ROS levels in these different cell types. Cells were electroporated with vectors allowing expression of a STAT5 shRNA (shST5) targeting both STAT5 isoforms or a control shRNA (shluc) and the GFP protein. STAT5 but not STAT3 was specifically targeted by $\operatorname{shST} 5$ as determined by Western blot and knockdown efficiency was evaluated by band intensity quantification (Figure 2C and 2D). As the emission spectrum of GFP and H2DCFDA overlap, transfected cells were then stained with the CellROX probe to measure ROS levels in $\mathrm{GFP}^{+}$cell populations (Figure 2E). Inhibition of STAT5 expression significantly decreased ROS production indicating that STAT5 activity directly enhanced ROS levels in Bcr-Abl-expressing cells. 


\section{Persistent STAT5 activity inhibits expression of catalase and GIrx1 in CML cells}

Oxidative stress is the result of an imbalance between ROS generation and antioxidant defenses [30]. We then tested whether STAT5 activity could regulate expression of detoxifying enzymes and scavengers in Bcr-Abl expressing cells by qRT-PCR experiments. We included the two STAT5-regulated genes: PIM1 and $\mathrm{CISH}$ as positive controls in these assays (Supplementary Table S1). First, we characterized the antioxidant gene expression profile in $\mathrm{Bcr}^{-\mathrm{Abl}^{+}}$cells treated or not with IM.
Among the 28 main antioxidant genes tested, expression of two genes: Catalase (CAT) and Glutaredoxin-1(GLRX1) were significantly upregulated in KU812 and K562 cells (Supplementary Figure S1 and S2). We found that IM induced the expression of $C A T(2.1 \mathrm{x}$ and $2.5 \mathrm{x}$ fold increase in KU812 and K562 cells, respectively) and GLRX1 (2.8x and 3.4x fold increase in KU812 and K562 cells) while $P I M 1$ and $C I S H$ gene expression were downregulated after IM treatment (Figure 3A). These results were also confirmed by Western blot analysis (Figure 3B). Importantly, we also found that expressions of $C A T$ and $G L R X 1$ were reduced in primary leukemic cells from CML

\section{A}

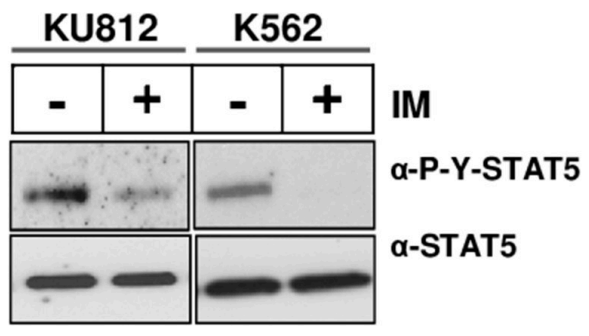

B

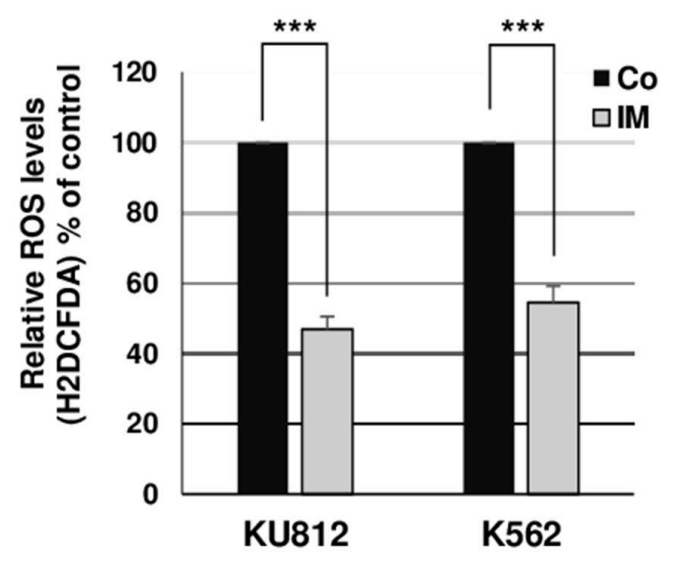

C

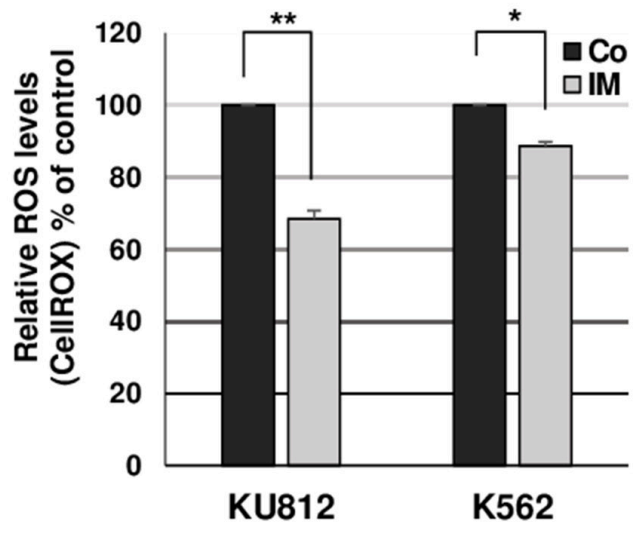

Figure 1: Bcr-Abl induces ROS production in leukemia cells. A. Lysates from KU812 and K562 cells treated (+) or not (-) with $1 \mu \mathrm{M}$ of IM for $15 \mathrm{~h}$ were analyzed by Western blotting with indicated antibodies. Results are the mean of 3 independent experiments. B. Statistical analysis showing relative ROS levels (\% of control) detected in KU812 and K562 cells treated or not (Co) with $1 \mu \mathrm{M}$ IM for $15 \mathrm{~h}$. Cells were incubated with the ROS sensitive fluorescent dye H2DCFDA $(5 \mu \mathrm{M})$ and intracellular ROS levels were monitored by flow cytometry $\left(\mathrm{n}=11\right.$ data are mean $\left.\pm \mathrm{SEM},{ }^{* * *} \mathrm{p}<0.001\right)$. C. Statistical analysis showing relative ROS levels $(\%$ of control) detected in KU812 and K562 cells treated or not (Co) with $1 \mu \mathrm{M}$ IM for $15 \mathrm{~h}$ and stained with the ROS sensitive probe CellROX ( $\mathrm{n}=3$, data are mean $\pm \mathrm{SEM}$. $\left.* \mathrm{p}<0.05 ; * *^{*}<0.01\right)$. 
A

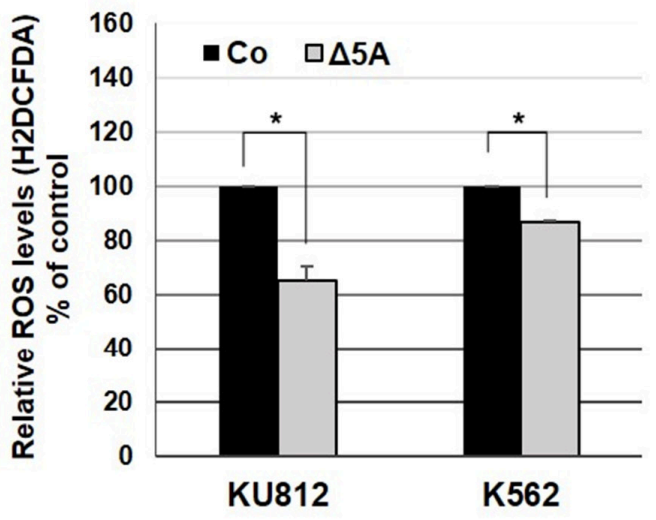

C

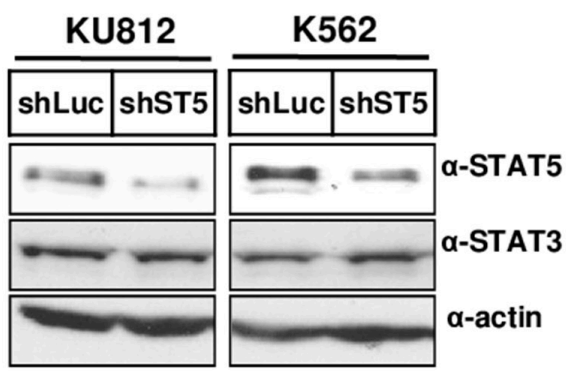

B

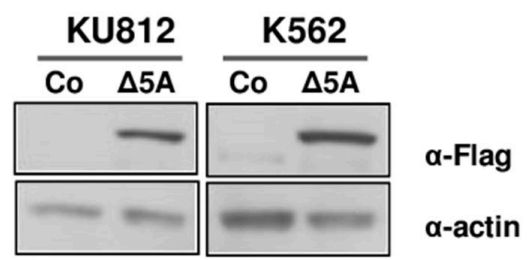

D

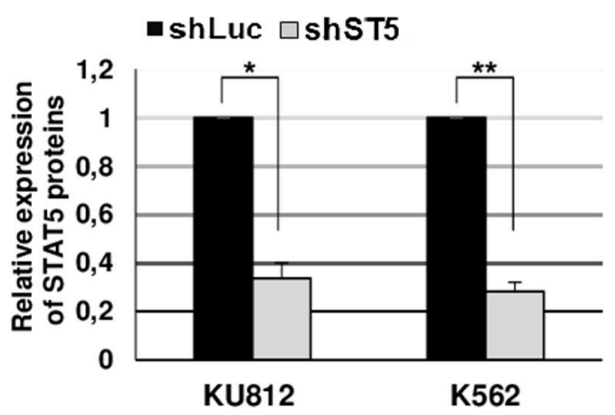

E

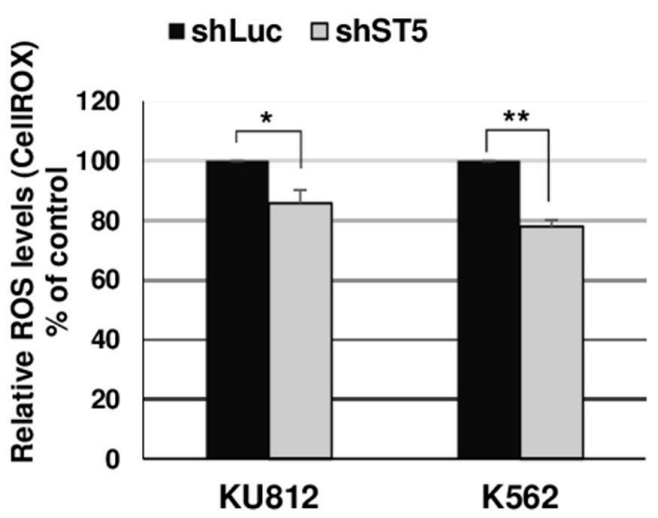

Figure 2: STAT5 promotes ROS production in Bcr-Abl+ leukemia cells. A. KU812, K562 cell lines were transfected with a dominant negative Flag-STAT5A $\Delta 749-\triangle \mathrm{CD} 4(\triangle 5 \mathrm{~A})$ bicistronic construct or empty vector (Co). Cells were next incubated with H2DCFDA $(5 \mu \mathrm{M})$ and APC-conjugated anti-CD4 antibody to determine ROS levels in $\mathrm{CD}^{+}$transfected cells. $(\mathrm{n}=3$, data are mean $\pm \mathrm{SEM}, * \mathrm{p}<0.05)$. B. Extracts from transfected KU812 and K562 cells were prepared and analyzed by Western blotting with an anti-Flag antibody to verify expression of the dominant negative STAT5A $\Delta 749$ mutant $(\Delta 5 \mathrm{~A})$. Actin served as a loading control ( $\alpha$-actin). C. KU812 and K562 cells were transfected with shST5/GFP or control shLuc/GFP vectors. Cell lysates were prepared 3 days after transfection and analyzed by Western blotting with indicated antibodies $(n=3)$.D. Quantification of Western blot (ImageJ software) was performed to determine the relative expression of STAT5 (ratio STAT5/actin) in cells transfected with shST5 or shLuc expression vectors (n=3). E. KU812 and K562 cells transfected with shST5/GFP or control shLuc/GFP vectors were stained with CellROX at 3 days post-transfection to quantify ROS levels in $\mathrm{GFP}^{+}$cells $(\mathrm{n}=5$, data are mean $\pm \mathrm{SEM}, * \mathrm{p}<0.05 ; * * \mathrm{p}<0.01)$. 
A
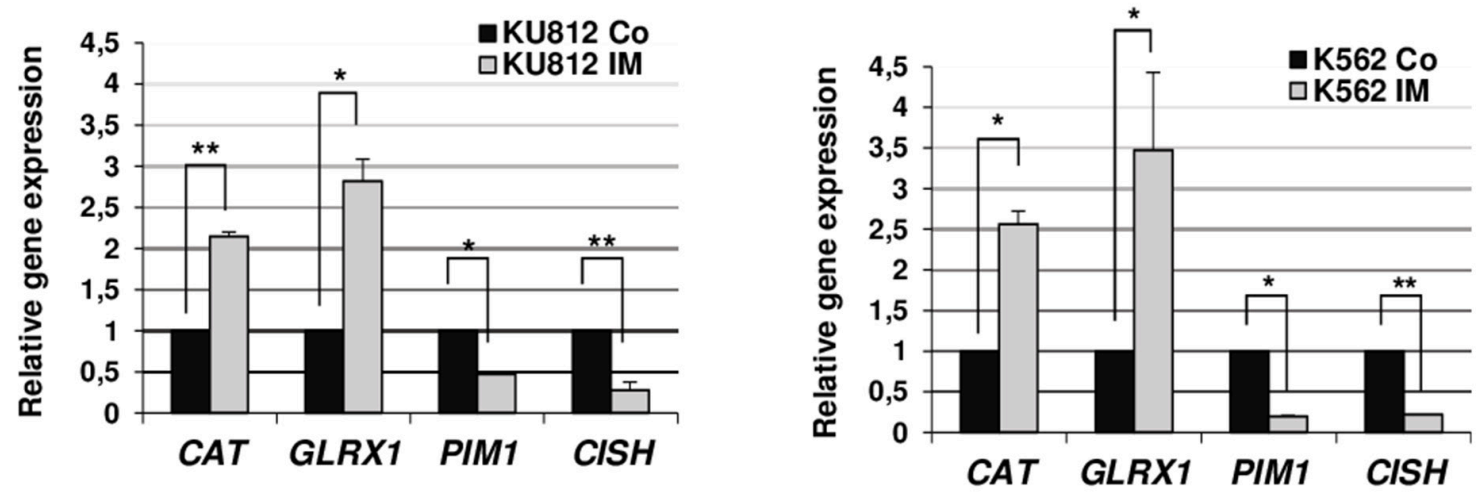

B
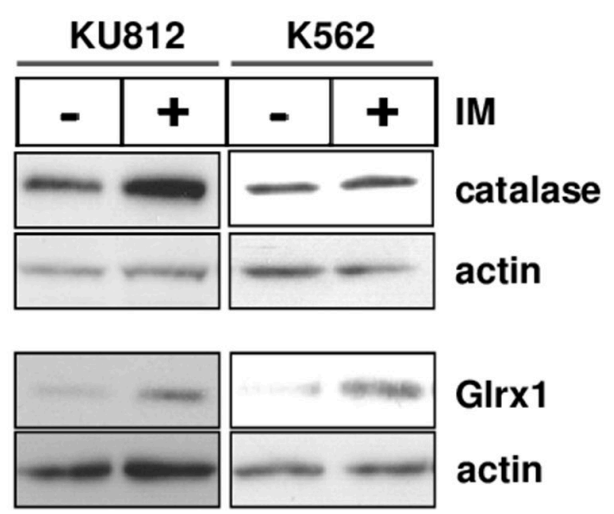

C

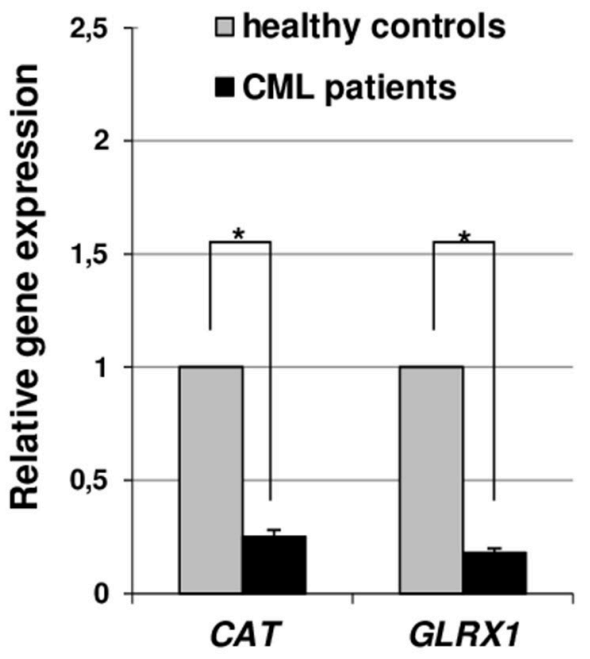

D

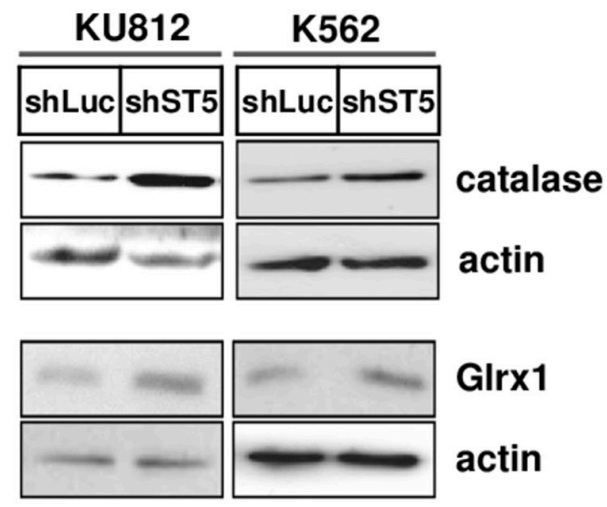

Figure 3: STAT5-dependent repression of Catalase and GLRX1 expression in CML cells. A. qRT-PCR analysis of CAT, GLRXI, CISH and PIMI transcripts in KU812 (left) and K562 (right) cells treated or not with IM $(1 \mu \mathrm{M})$ for $15 \mathrm{~h}$. Results are presented as the fold changes in gene expression in IM-treated cells normalized to internal control genes (GAPDH and ACTB) and relative to untreated cells (normalized to 1) $\left(\mathrm{n}=3\right.$ in triplicates, data are mean $+/$ - SEM. $\left.{ }^{*} \mathrm{p}<0.01 ;{ }^{*} \mathrm{p}<0.05\right)$. B. Protein extracts from KU812 and K562 cells treated or not with IM $(1 \mu \mathrm{M})$ were analyzed by Western blotting to detect catalase and Glrx1 protein expression. Actin served as a loading control. ( $\mathrm{n}=3)$. C. qRT-PCR analysis of CAT and GLRX1 expression in leukemia cells from CML patients $(\mathrm{n}=35)$ and peripheral mononuclear (PMN) cells from healthy donors ( $\mathrm{n}=10)$. D. Levels of catalase and Glrx1 proteins in KU812 and K562 cells transfected with shST5/GFP or shLuc/GFP vectors were also determined by Western blot analysis $(\mathrm{n}=3)$. 
patients at diagnosis compared to mononuclear cells from healthy donors (Figure 3C). These data indicated that Bcr-Abl signaling inhibits expression of both enzymes in CML cells. We next evaluated the contribution of STAT5 in the regulation of catalase and Glrx 1 protein expression and found that RNA interference-mediated knockdown of STAT5 in Bcr-Abl ${ }^{+}$leukemia cells increased the expression of catalase and Glrx1 (2 to 3 fold) (Figure 3D and Supplementary Figure S3A). The dominant negative $\triangle 5 \mathrm{~A}$ mutant also induced catalase protein expression and, as expected, inhibited Pim-1 expression in KU812 cells (Supplementary Figure S3B)

\section{Oncogenic STAT5 signaling promotes ROS production and down-regulation of catalase and Glrx1 in hematopoietic cells}

To confirm that persistent STAT5 activity is required for this inhibitory effect, we used $\mathrm{Ba} / \mathrm{F} 3$ cells transformed by a constitutively active STAT $5 \mathrm{~A} 1 * 6$ mutant $(\mathrm{Ba} / \mathrm{F} 35 \mathrm{~A} 1 * 6)$. We first measured ROS levels in $\mathrm{Ba} /$ $\mathrm{F} 35 \mathrm{~A} 1 * 6$ and control $\mathrm{Ba} / \mathrm{F} 3$ cells. Constitutive tyrosine phosphorylation of STAT5 and higher ROS levels were evidenced in $\mathrm{Ba} / \mathrm{F} 35 \mathrm{~A} 1 * 6$ cells compared to IL-3-deprived control cells (Figure 4A-4C). Tyrosine phosphorylation of STAT5 and ROS level were also enhanced by IL-3 in control cells. The antioxidant gene expression profile was then determined in $\mathrm{Ba} / \mathrm{F} 35 \mathrm{~A} 1 * 6$ cells by qRT-PCR assays using murine primers (Supplementary Table S2). Results showed that only cat and glrx 1 expressions were affected in these transformed cells (Supplementary Figure S4). Levels of cat and glrx 1 mRNAs and proteins were found to be decreased while expression of pim 1 and cish control genes were strongly induced in $\mathrm{Ba} / \mathrm{F} 35 \mathrm{~A} 1 * 6$ cells (Figure 4D, 4E). Collectively, these data supported our findings that oncogenic activation of STAT5 triggers ROS production through mechanisms involving inhibition of catalase and Glrx1 expression.

\section{Catalase and GIrx1 reduce ROS production in $\mathbf{P h}^{+}$leukemia cells}

Glrx1 is a glutathione-dependent enzyme that maintains and regulates the cellular redox state and redoxdependent signaling pathways while catalase converts the ROS hydrogen peroxide $\left(\mathrm{H}_{2} \mathrm{O}_{2}\right)$ to water and oxygen [30]. We therefore analyzed the requirement of these two proteins in the regulation of ROS levels in $\mathrm{Bcr}_{-} \mathrm{Abl}^{+}$cells. A bicistronic vector carrying a Flag-Glrx1 and the GFP was introduced in KU812 and K562 cells and ROS levels were determined in $\mathrm{GFP}^{+}$cell populations after staining with CellROX. Forced expression of Glrx1 induced a moderate but significant reduction of ROS levels in both cell types (17\% and 15\% decrease in KU812 and K562 cells respectively) (Figure 5A, 5B). The presence of catalase is mainly detected in the cytoplasm and peroxisomes but reports also indicated that catalase is a membrane-bound extracellular enzyme [31]. We added catalase to the culture medium of K562 and KU812 cells and next measured intracellular ROS levels to find that catalase strongly reduced ROS levels in both leukemic cell lines (56\% and 51\% decrease in KU812 and K562 cells respectively) (Figure 5C).

\section{Catalase induces growth arrest and quiescence of $\mathbf{P h}^{+}$leukemia cells}

The strong reduction of ROS level induced by exogenous catalase in Bcr-Abl-expressing cells prompted us to analyze the impact of this enzyme on cell growth. We observed that KU812 and K562 cells stopped dividing after catalase addition (Figure 5D). Cell viability and apoptosis were not affected but changes in cell cycle phase distributions were observed (Supplementary Figure S5A-S5C). Catalase increased the number of cells in the G0 phase with a concomitant decrease in the number of G1 cells, providing evidence that KU812 and K562 cells enter quiescence into the G0/G1 phase (Figure 5E, 5F and Supplementary Figure S5D). We verified the specificity of catalase activity in our experiments using 3-amino1,2,4-triazole (3-AT), a catalase inhibitor. We showed that addition of 3-AT in the culture medium reduced the effect of catalase on ROS levels and leukemic cell quiescence (Supplementary Figure S6).

\section{STAT5-mediated oxidative stress is reduced in quiescent $\mathbf{P h}^{+}$leukemia cells}

It is well established that the maintenance of quiescent leukemic and normal hematopoietic stem cells is dependent on the bone marrow microenvironment and low ROS levels, suggesting that bone marrow stromal cells might deliver signals that could regulate intracellular ROS production and signaling pathways in leukemic cells [32-35]. We then designed experiments in which KU812 cells were cultured over human stromal cell monolayers using HS-27A cells, a bone marrowderived stromal cell line [36]. KU812 cells were cocultured with HS-27A cells during three days or grown alone in medium or conditioned medium from HS-27A cells as controls. Cell cycle analysis was performed on leukemic cells and showed that the contact with HS-27A cells increases the number of quiescent/G0 leukemic cells (Figure 6A). ROS level was also measured and found to be reduced in KU812 cells co-cultured with stromal cells (Figure 6B). No effect was observed when leukemic cells were grown in conditioned media from HS-27A indicating that contact with stromal cells is required for both induction of quiescence and downregulation of ROS level. Finally, we analyzed whether HS-27A cells could directly affect STAT5 phosphorylation, catalase and Glrx1 expression in leukemic cells. Western blot 
A

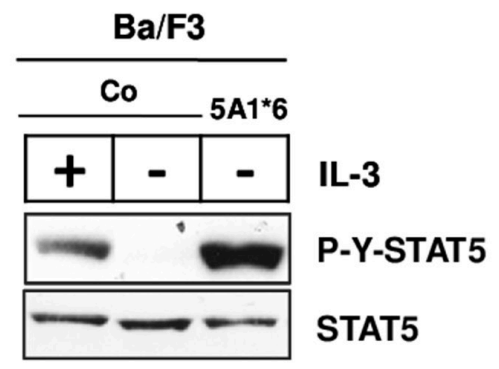

B

\section{$\mathrm{Ba} / \mathrm{F3}$}
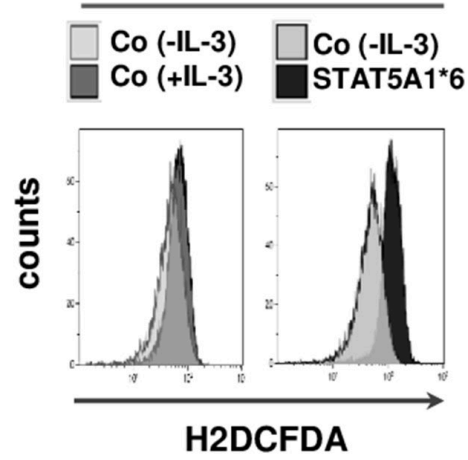

C

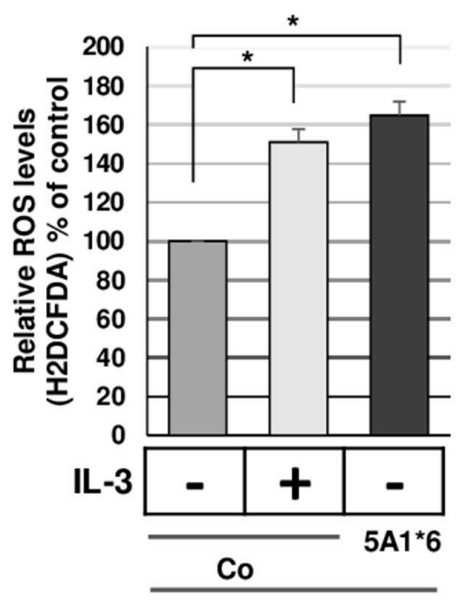

$\mathrm{Ba} / \mathrm{F3}$
D

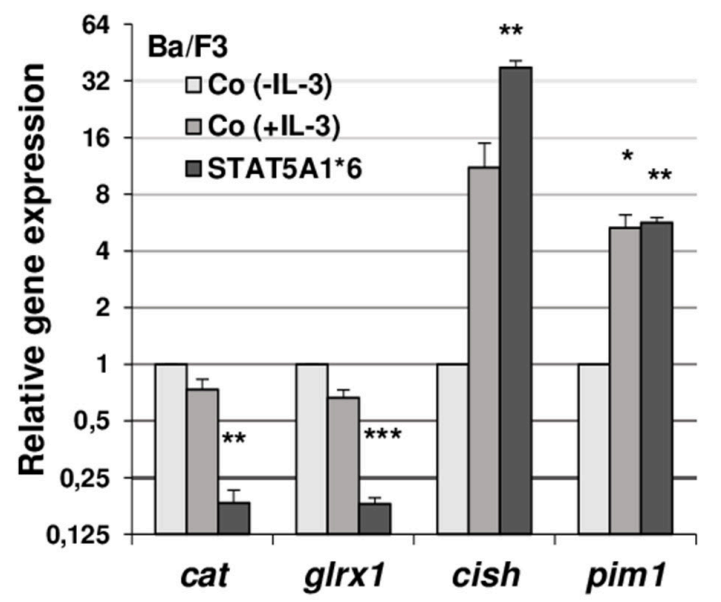

E

$\mathrm{Ba} / \mathrm{F3}$

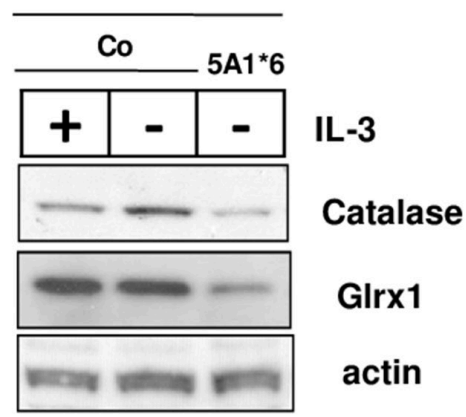

Figure 4: Tyrosine-phosphorylated STAT5 induces ROS production and inhibits catalase and Glrx1 expression in $\mathbf{B a} / \mathbf{F} 3$ cells. A. Extracts prepared from $\mathrm{Ba} / \mathrm{F} 3$ cells stimulated or not with $\mathrm{IL}-3$ and from $\mathrm{Ba} / \mathrm{F} 3$ cells stably expressing STAT5A1*6 were analyzed by Immunoblotting with indicated antibodies. Results are the mean of 3 independent experiments. B. Representative flow cytometry histogram of Ba/F3 cells stimulated (+IL-3) or not (-IL-3) with IL-3 and Ba/F3 cells expressing STAT5A $1 * 6$ mutant. Cells were incubated with the ROS sensitive fluorescent probe H2DCFDA $(5 \mu \mathrm{M})$ and intracellular ROS levels were determined by flow cytometry. C. Statistical analysis showing relative ROS levels (\% of control) detected in $\mathrm{Ba} / \mathrm{F} 3$ cells stimulated or not with IL-3 and $\mathrm{Ba} / \mathrm{F} 3$ cells expressing STAT5A1*6 $(\mathrm{n}=7$, data are mean $\pm \mathrm{SEM}$. * $\mathrm{p}<0.05)$. D. qRT-PCR analysis of cat, glrx 1 , cish and pim 1 transcriptsin $\mathrm{Ba} / \mathrm{F} 3$ cells transformed by constitutively active STAT5A $1 * 6$ mutant and control Ba/F3 cells grown in presence or absence of IL-3 (4h starvation). Results are presented as fold changes in gene expression in $\mathrm{Ba} / \mathrm{F} 35 \mathrm{~A} 1 * 6$ and control $\mathrm{Ba} / \mathrm{F} 3$ cells $(+\mathrm{IL}-3)$ normalized to internal control genes (gapdh) and relative to control $\mathrm{Ba} / \mathrm{F} 3$ cells (-IL-3) normalized to $1(\mathrm{n}=3$ in triplicates, data are mean $+/-\mathrm{SEM} . * * * \mathrm{p}<0.001$; $\left.{ }^{* *} \mathrm{p}<0.01 ;{ }^{*} \mathrm{p}<0.05\right)$. E. Expression of catalase and Glrx 1 in $\mathrm{Ba} / \mathrm{F} 35 \mathrm{~A} 1 * 6$ and control Ba/F3 cells grown in the presence or not of IL-3 (4hr starvation) as determined by Western blot analysis. Actin served as a loading control $(\mathrm{n}=3)$. 
A

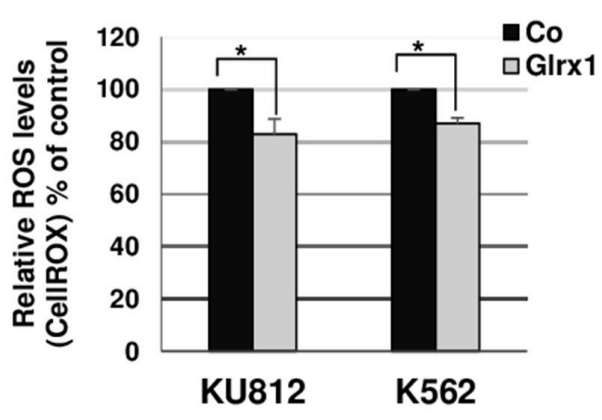

C

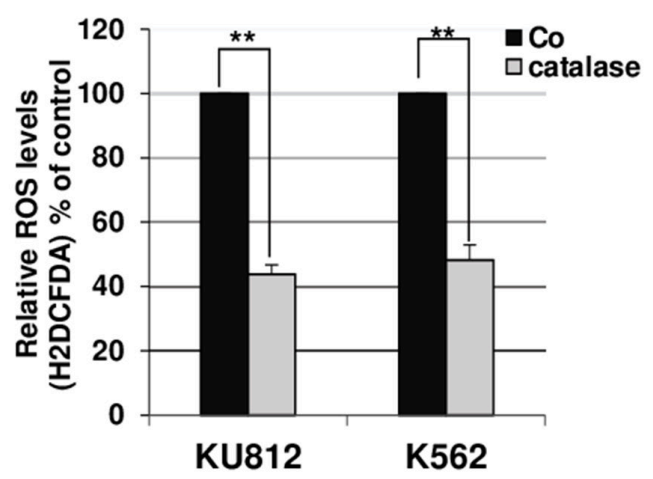

E

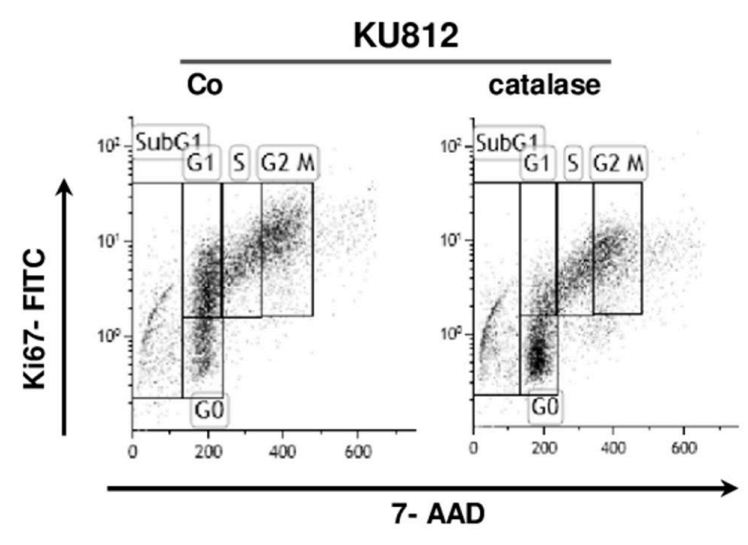

B

D

$\mathbf{F}$
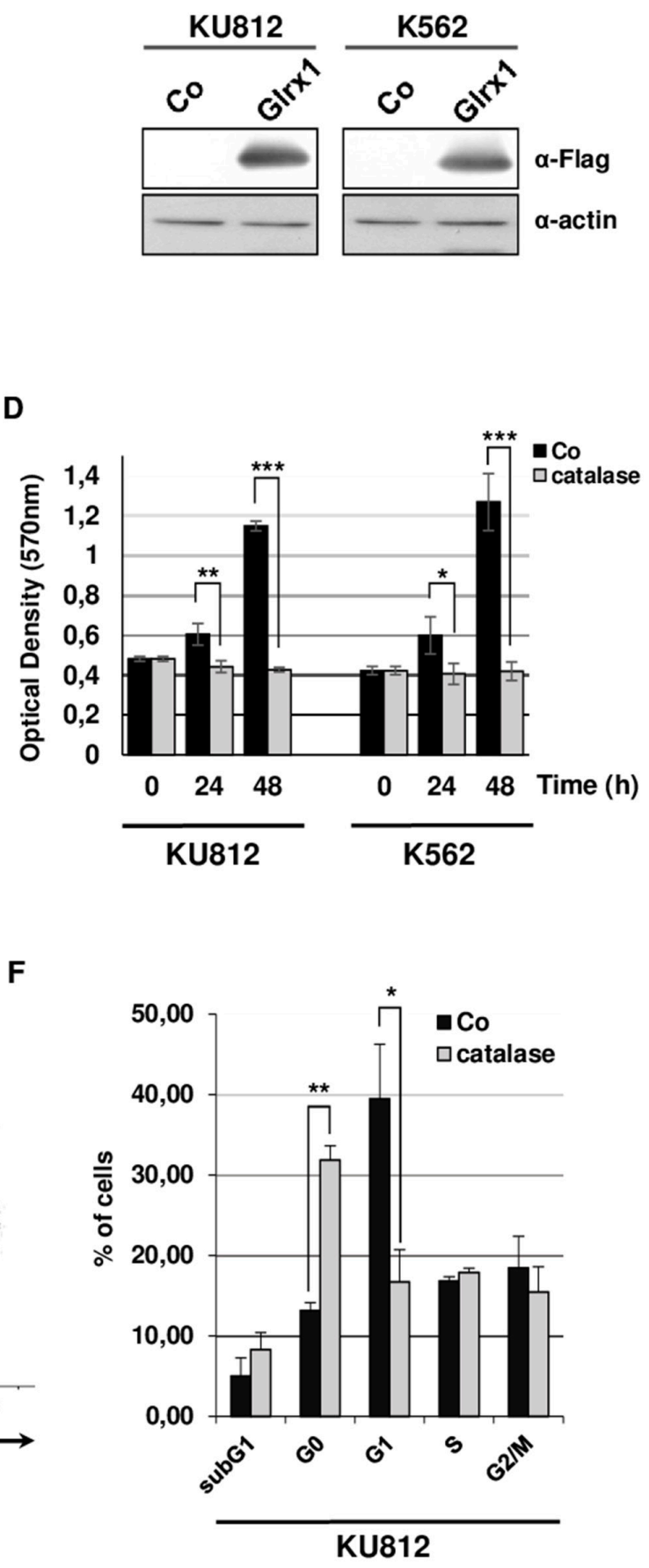

Figure 5: Effects of catalase and Glrx1 on ROS production and proliferation of Bcr-Abl+ leukemia cells. A. KU812 and K562 cells were transfected with Glrx1/GFP (Glrx1) or empty/GFP (Co) expression vectors. At 2 days post transfection, cells were stained with CellROX to detect ROS levels in $\mathrm{GFP}^{+}$cells $(\mathrm{n}=3$, data are mean $\pm \mathrm{SEM} . * \mathrm{p}<0.05)$. B. Extracts from transfected cells were subjected to Western blot analysis to evaluate expression of the Flag-Glrx1 protein with an anti-Flag antibody. Actin served as loading control. C. KU812 and K562 cells were cultured for $48 \mathrm{~h}$ in the presence or not of catalase $(0.5 \mathrm{mg} / \mathrm{ml})$. Cells were then stained with H2DCFDA to measure intracellular ROS levels $(\mathrm{n}=3$, data are mean \pm SEM. $* * \mathrm{p}<0.01)$. D. Growth kinetics of KU812 and K562 cells cultured in absence $(\mathrm{Co})$ or presence of catalase $(0.5 \mathrm{mg} / \mathrm{ml})$ were determined by MTT assays $(\mathrm{n}=3$ in triplicates, data are mean \pm SEM *p $<0.05 ; * * \mathrm{p}<0.01 ; * * * \mathrm{pp}<0.001)$. E. KU812 cells exposed or not (Co) to catalase were stained with 7-amino-actinomycin D (7-AAD) and an Alexa Fluor H488-conjugated anti-Ki67 antibody. Cell cycle phase distributions were then estimated by flow cytometry. One representative experiment is shown. F. The histogram presents the percentage of KU812 cells exposed or not (Co) to catalase in sub-G1 (apoptotic fraction) and in each phase of the cell cycle. $\left(\mathrm{n}=3\right.$, data are mean \pm SEM. $\left.{ }^{* *} \mathrm{p}<0.01 ; * \mathrm{p}<0.05\right)$ 
analysis showed a decrease in STAT5 phosphorylation which was accompanied by an upregulation of catalase and Glrx1 expression (Figure 6C). Interestingly, conditioned media from HS-27A was also able to slightly reduce STAT5 phosphorylation and to weakly increase

A

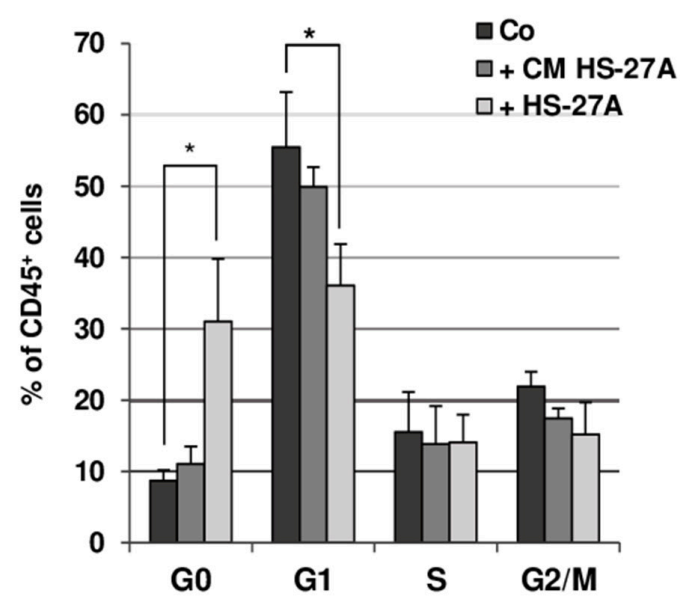

C

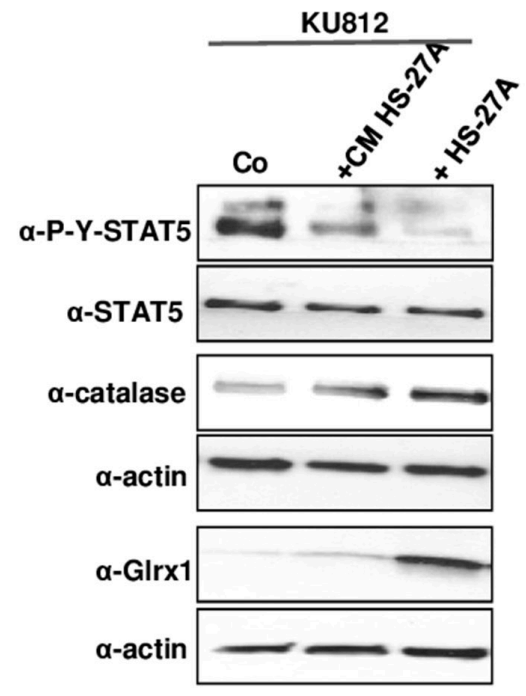

catalase and Glrx1 expression. These data indicated that tyrosine phosphorylation is probably a key determinant of STAT5-mediated repression of catalase and Glrx1 and oxidative stress in Bcr-Abl-expressing cells. They also suggest that catalase expression by reducing ROS level

B

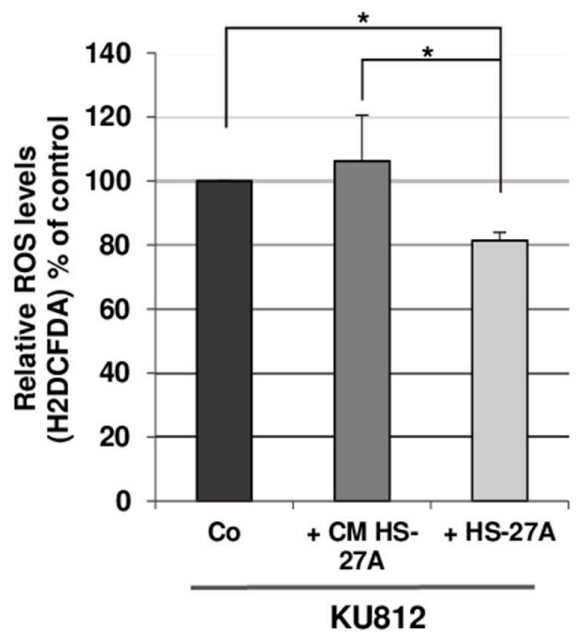

D

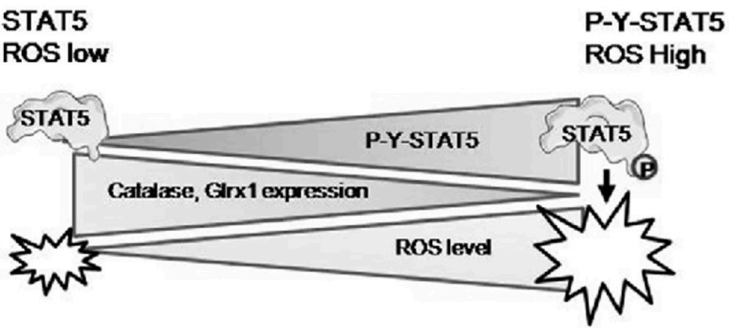

Figure 6: Contact with stromal cells promotes quiescence and reduction of STAT5-mediated oxidative stress in BcrAbl+ leukemia cells. A. KU812 $\left(10^{5}\right.$ cells $\left./ \mathrm{ml}\right)$ cells were cultured alone in medium (Co) or in HS-27A conditioned medium (+CM HS27A) or on HS-27A cell monolayers for $72 \mathrm{~h}$ (+HS-27A). Cells were stained with 7-AAD and an Alexa Fluor H488-conjugated anti-Ki67 antibody. Concomitant staining with an APC-conjugated anti-CD45 antibody was performed to distinguish leukemic and stromal cells. Cell cycle phase distributions were estimated by flow cytometry. The histogram presents the percentage of leukemic cells $\left(\mathrm{CD} 45^{+}\right.$cells) in the sub-G1 (apoptotic fraction) and cell cycle phases $\left(n=3\right.$, data are mean \pm SEM. $\left.{ }^{*} p<0.05\right)$. B. Cells were stained with the ROS sensitive dye H2DCFDA $(5 \mu \mathrm{M})$ and an APC-conjugated anti CD45 antibody. ROS levels were then determined in leukemic cells (CD45 ${ }^{+}$cells) by FACS analysis $(n=3$ data are mean \pm SEM. $* \mathrm{p}<0.05)$. C. KU812 cells cultured alone without $(\mathrm{Co})$ or with HS-27A conditioned medium ( $+\mathrm{CM}$ HS-27A) or on HS-27A cell monolayers (+HS-27A) were isolated using an immunomagnetic CD45 selection kit. KU812 cell extracts were then prepared and subjected to Western blot analysis with indicated antibodies. $(n=3)$. D. Hypothetical model for the role of STAT5 as an inducer of ROS production in CML cells. The pro-oxidant activity of STAT5 is regulated by tyrosine phosphorylation. Constitutive activation of STAT5 (P-Y-STAT5) promotes oxidative stress by repressing expression of catalase and Glrx1. Dephosphorylation of STAT5 might allow the re-expression of catalase and Glrx1 and the decrease of ROS levels in leukemic cells. 
might favour quiescence of leukemic cells in contact with stromal cells.

\section{DISCUSSION}

Oxidative stress has been found in many cancers, including hematologic malignancies and elevated ROS levels have been detected in hematopoietic cells transformed by JAK2 ${ }^{\mathrm{V} 617 \mathrm{~F}}$, FLT3-ITD and Bcr-Abl oncogenes [21-23]. STAT5 was shown to regulate ROS production in leukemic cells with opposite effects and through distinct mechanisms that remain largely unclear [21, 25-28]. Our present work provides compelling evidence that activation of STAT5 induced by Bcr-Abl promotes oxidative stress in CML cells by repressing catalase and Glrx1 expression. Moreover, we found that expression of a constitutively active and oncogenic STAT5A mutant in hematopoietic cells is sufficient to observe this repression. Inhibition of both enzymes occurs at mRNA and protein levels indicating that STAT5 might directly or indirectly regulate expression of $C A T$ and GLRX1 genes. The inhibitory effect of the dominant negative STAT5A $\triangle 749$ mutant on the regulation of ROS level and repression of catalase would suggest that transcriptional activity of STAT5 is necessary for the regulation of both enzymes [37]. The JAK2 $2^{\mathrm{V} 617 \mathrm{~F}}$ oncogene was recently shown to repress catalase expression via a PI3 kinase/Akt-dependent pathway in murine hematopoietic cells and human $\mathrm{CD}^{+} 4^{+}$cells [22]. It is then conceivable that STAT5 and PI3-Kinase/Akt signalling act in concert to repress catalase expression in leukemic cells transformed by Bcr-Abl. Previous works illustrating a STAT5/PI3-kinase interaction in myeloid leukemias are in line with this putative regulatory mechanism [38]. Our data demonstrated that Glrx1 and catalase reduced ROS levels in Bcr-Abl-expressing cells. Glrx1 belongs to the family of glutaredoxins which utilize the reducing power of glutathione to catalyse disulfide reductions and protein deglutathionylation [39]. Glrx1 is the most abundant isoform and regulates the redox status of many proteins involved in signal transduction. However, the role of Glrx1 in the regulation of ROS production and protein glutathionylation in TKOs signalling is currently unknown. Reports indicated that oxidative stress promotes the S-glutathionylation of signalling proteins such as NFKB and STAT3 [40, 41]. The downregulation of Glrx1 expression observed in $\mathrm{Bcr}-\mathrm{Abl}^{+}$cells might then increase the redox sensitivity of these proteins. In contrast to the moderate effect of Glrx1 on ROS levels, catalase was found to be as efficient as Imatinib to reduce intracellular ROS production in $\mathrm{Bcr}_{-} \mathrm{Abl}^{+}$cells. Previous reports have shown that Bcr-Abl induced ROS accumulation in leukemic cells via activation of NADPH oxidases and a Rac2/MRC-cIII (Mitochondrial Respiratory Chain complex III) pathway $[15,42]$. These data suggest that catalase is probably an important detoxifying enzyme able to eliminate ROS generated by both types of sources in Bcr-Abl-expressing cells. They also strengthen our finding that downregulation of catalase expression is probably essential in ROS accumulation induced by constitutively active STAT5 proteins in leukemic cells and most importantly in primary patient-derived CML cells. Interestingly, we found that catalase not only reduced ROS levels but also induced growth arrest, driving BcrAbl-expressing cells into a G0/quiescent state. These data indicate that ROS production directly affects BcrAbl-induced signaling pathways that are crucial for cell cycle progression. In support of this, overexpression of catalase has been shown to regulate cell cycle in vascular muscle smooth cells [43]. The contribution of catalase in the regulation of quiescence is also underscored by data obtained from the co-culture experiments aiming to mimic the bone marrow microenvironment of leukemia cells. We show that interaction with stromal cells promotes a decrease in STAT5 phosphorylation followed by an increase in catalase and Glrx1 expression and a reduction of ROS level in quiescent $\mathrm{Bcr}-\mathrm{Abl}^{+}$cells. These data also support our findings that repression or activation of catalase and Glrx 1 expression and consequently ROS production are regulated by the fine tuning of STAT5 activity through phosphorylation/dephosphorylationdependent mechanisms. Interestingly, catalase and STAT5 were previously shown to promote self-renewal and/ or quiescence of normal hematopoietic stem cells as well as leukemic stem cells [44-47]. Our results suggest that stromal-derived signals induce quiescence of Bcr$\mathrm{Abl}^{+}$leukemia cells in part, through a STAT5/catalase dependent pathway. In sharp contrast to these data and those published by others [25], reports indicated that STAT5A mediates a protective role against oxidative stress in CML stem cells/progenitors [27]. We also reported a similar antioxidant activity of STAT5A in pre-B leukemic cells [28]. However, we showed that this effect was only observed in cells expressing a non-tyrosine(Y694)phosphorylated form of STAT5A. The dephosphorylation of STAT5 as it is observed in Bcr-Abl-expressing cells when co-cultured with stromal cells might promote the protective role of the non-tyrosine-phosphorylated protein against an overproduction of ROS.

As summarized in Figure 6D, our work provides compelling evidence that sustained tyrosine phosphorylation of STAT5 induced by Bcr-Abl oncogene promotes oxidative stress in CML cells by repressing expression of two detoxifying enzymes, catalase and Glrx1. The dephosphorylation of STAT5 relieves this repression and consequently leads to the reduction of ROS production. Dephosphorylation might also unveil the protective role of STAT5 against oxidative stress through mechanisms that remain to be investigated. 


\section{MATERIALS AND METHODS}

\section{Cell culture and reagents}

Cell lines were obtained from the American Type Culture Collection (ATCC) and maintained according to the supplier's recommendations. $\mathrm{Ba} / \mathrm{F} 3$ cell lines expressing STAT5 mutants were previously reported [48]. Imatinib mesylate (IM) and catalase were purchased from Novartis (Basel, Switzerland) and Sigma-Aldrich (Lyon, France) respectively.

\section{CML patient samples}

Leukemic cells from peripheral blood samples (35 adult patients) collected at diagnosis (before treatment) and peripheral mononuclear cells from 10 healthy volunteers were used to analyze CAT and GLRXI gene expression. All samples were obtained after informed consent and approval by the ethics committee of the University Hospital of Tours.

\section{Co-cultures and magnetic cell separation}

HS-27A stromal cells were grown up to confluence in $150 \mathrm{~cm}^{2}$ flask. Medium was changed one day before starting the co-culture. $2.5 \times 10^{6} \mathrm{KU} 812$ cells were next added on stromal cell monolayers for 72 hours. To discriminate between stromal cells and leukemic cells in apoptosis, cell cycle and ROS measurement analysis by flow cytometry, non-adherent and adherent leukemic cells were first labelled with an APC-conjugated anti-CD45 antibody (Becton-Dickinson). Leukemic cells were also purified by immunomagnetic selection using the EasySep PE positive selection kit (StemCell Technologies). Isolated $\mathrm{CD} 45^{+}$cells were then used to determine protein expression according to Western blot procedure.

\section{Plasmids and transfections}

The coding regions of the dominant negative Stat5a $\triangle 749$ cDNA was amplified by PCR and cloned and subcloned in the pMACS4-IRESII vector (Miltenyi Biotec, Paris, France). Glutaredoxin-1 cDNA was amplified by PCR and cloned at NotI/SalI of the pIREShrGFP1a vector.

Short hairpins against human Stat5a/5b genes (shST5: GGAGAACCTCGTGTTCCTG) was subcloned at the BbsI site of psiRNA-h7SK-GFPzeo vector (Invivogen, Toulouse, France). For control, a shRNA targeting firefly luciferase was used (psiRNA-h7SKGFPzeo-luc).

For transient transfection assays, cells were electroporated $(270 \mathrm{~V}, 960 \mu \mathrm{F})$ with the different constructs $(50 \mu \mathrm{g})$. Transfected cells were expanded for 24-48 hours in medium before analysis.

\section{Analysis of ROS levels}

Intracellular reactive oxygen species (ROS) production was measured using CellROX Deep Red Reagent (life technologies, Saint Aubin, France) or 5-(and-6)-chloromethyl-2', 7'-dichlorodihydrofluorescein diacetate, acetyl ester (CM-H2DCFDA) (Invitrogen, Carlsbad, United States). Cells $\left(0.5 \times 10^{6}\right)$ were washed with PBS (phosphate-buffered saline) and stained with $5 \mu \mathrm{M}$ CellROX for $30 \mathrm{~min}$ or $5 \mu \mathrm{M}$ CM-H2DCFDA for $10 \mathrm{~min}$ at $37^{\circ} \mathrm{C}$. Cells were then analyzed by flow cytometry on a Beckman Coulter Gallios or a Becton Dickinson Accuri ${ }^{\mathrm{TM}}$ C6 flow cytometer.

\section{Cell cycle and apoptosis analysis}

Cells were stained for $30 \mathrm{~min}$ at room temperature with 7-amino-actinomycin D (7-AAD) (Sigma-Aldrich, Lyon, France) and anti-Ki67-Alexa Fluor 488 monoclonal antibody (Becton-Dickinson, Franklin Lakes, United States) as previously described [49]. For apoptosis studies, cells were stained $\left(0,25 \times 10^{6}\right.$ cells $)$ in buffer containing FITC-AnnexinV and 7-amino-actinomycin D (7-AAD) (Beckmann Coulter, Fullerton, United States) for 15 min at $4^{\circ} \mathrm{C}$ and then analyzed by FACS.

\section{qRT-PCR analysis}

RNA samples were reverse-transcribed using SuperScript ${ }^{\circledR V I L O ~ c D N A ~ S y n t h e s i s ~ k i t ~(I n v i t r o g e n, ~}$ Carlsbad, United States) as recommended by the supplier. The resulting cDNAs were used for quantitative realtime PCR (qRT-PCR). PCR primers (Supplementary Tables S1 and S2) were designed with the ProbeFinder software (Roche Applied Sciences, Basel, Switzerland) and used to amplify the RT-generated cDNAs. qRTPCR analyses were performed on the Light Cycler 480 thermocycler II (Roche) Both GAPDH (glyceraldehyde3-phosphate dehydrogenase) and $A C T B$ (actin beta) were used as reference genes for normalization of qRT-PCR experiments. Each reaction condition was performed in triplicate. Relative gene expression was analyzed using the $2^{-\Delta \Delta \mathrm{Ct}}$ method [50].

\section{Western blotting and antibodies}

NP40 cell lysates (1\% NP40, 10\% glycerol, 0.05 $\mathrm{M}$ Tris $\mathrm{pH} 7.5,0.15 \mathrm{M} \mathrm{NaCl}, 1 \mathrm{mM}$ PMSF, protease and phosphatase Inhibitor cocktails) (Roche and Thermo Scientific, respectively) were resuspended in Laemmli's $2 \mathrm{x}$ buffer, separated on SDS/PAGE and blotted onto nitrocellulose membrane (GE Healthcare, Little Chalfont, United Kingdom). Blots were incubated with the following antibodies (Abs): P-Y ${ }^{694 / 699}$-STAT5, catalase (Cell Signaling Technology, Danvers, United States), STAT5 (BD Transduction Laboratories, Franklin Lakes, United States), actin (Santa Cruz, Dallas, United States), Flag M2 
(Stratagene, Santa Clara, United States), Glutaredoxin1 (Glrx1) (R\&D, Minneapolis, United States). Membranes were developed with the ECL chemiluminescence detection system (GE Healthcare, Little Chalfont, United Kingdom) using specific peroxidase (HRP) conjugated to rabbit or mouse $\operatorname{IgG}$ antibodies (Cell signaling Technology, Danvers, United States) or goat IgG (Santa Cruz, Dallas, United States).

\section{MTT assays}

Cell viability and proliferation were studied using an MTT cell proliferation assay. Briefly, $0.5 \times 10^{5}$ cells were incubated in $100 \mu \mathrm{l}$ of X-Vivo red phenol free medium (Lonza, Basel, Switzerland) in 96 well plates. Cells were treated with $10 \mu \mathrm{l}$ of MTT working solution ( $5 \mathrm{~g} / \mathrm{l}$ of Methylthiazolyldiphenyl-tetrazolium bromide) during 4 hours. Cells were then lysed overnight at $37^{\circ} \mathrm{C}$ with 100 $\mu \mathrm{l}$ of SDS $10 \%, \mathrm{HCl} 0.003 \%$. Optical density (OD) at $570 \mathrm{~nm}$ was measured using a spectrophotometer (Dynex, Chantilly, United States).

\section{Statistical analysis}

Data are presented as mean \pm SEM ( $n=$ number of individual measurements). The Student's t-test was used to compare two means and to determine significant differences. Differences between values were considered significant $(*)$ when $\mathrm{p}<0.05$; very significant $(* *)$ when $\mathrm{p}<0.01$ and highly significant $(* * *)$ when $\mathrm{p}<0.001$. All calculations were performed using the GraphPad Prism 6 software.

\section{CONFLICTS OF INTEREST}

The authors declare that they have no conflicts of interest.

\section{GRANT SUPPORT}

This study was supported by Conseil Regional Centre, Ligue Contre le Cancer interregional Grand Ouest, CANCEN society, "Sapin de l'Espoir Contre le Cancer", International Rotary (Club of Blois), Federative Programme FHU GOAL. RM was supported by grants SFB-F28 and SFB-F47 from the Austrian Science Fund (FWF). JB was supported by CNRS, Conseil Regional Centre and Ligue Contre le Cancer (Comité Indre et Loire).

\section{REFERENCES}

1. Bunting KD. STAT5 signaling in normal and pathologic hematopoiesis. Front Biosci. 2007; 12:2807-20.

2. Leonard WJ, O'Shea JJ. Jaks and STATs: biological implications. Annu Rev Immunol. 1998; 16:293-322.
3. Mizuki M, Fenski R, Halfter H, Matsumura I, Schmidt R, Müller C, Grüning W, Kratz-Albers K, Serve S, Steur C, Büchner T, Kienast J, Kanakura Y, et al. Flt3 mutations from patients with acute myeloid leukemia induce transformation of 32D cells mediated by the Ras and STAT5 pathways. Blood. 2000; 96:3907-14.

4. Harir N, Boudot C, Friedbichler K, Sonneck K, Kondo R, Martin-Lannerée S, Kenner L, Kerenyi M, Yahiaoui S, Gouilleux-Gruart V, Gondry J, Bénit L, Dusanter-Fourt I, et al. Oncogenic Kit controls neoplastic mast cell growth through a Stat5/PI3-kinase signaling cascade. Blood. 2008; 112:2463-73.

5. Shuai K, Halpern J, ten Hoeve J, Rao X, Sawyers CL. Constitutive activation of STAT5 by the BCR-ABL oncogene in chronic myelogenous leukemia. Oncogene. $1996 ; 13: 247-54$.

6. James C, Ugo V, Le Couédic JP, Staerk J, Delhommeau F, Lacout C, Garçon L, Raslova H, Berger R, BennaceurGriscelli A, Villeval JL, Constantinescu SN, Casadevall N, Vainchenker W. A unique clonal JAK2 mutation leading to constitutive signalling causes polycythaemia vera. Nature. 2005; 434:1144-48.

7. Levine RL, Wadleigh M, Cools J, Ebert BL, Wernig G, Huntly BJ, Boggon TJ, Wlodarska I, Clark JJ, Moore S, Adelsperger J, Koo S, Lee JC, et al. Activating mutation in the tyrosine kinase JAK2 in polycythemia vera, essential thrombocythemia, and myeloid metaplasia with myelofibrosis. Cancer Cell. 2005; 7:387-97.

8. Hoelbl A, Kovacic B, Kerenyi MA, Simma O, Warsch W, Cui Y, Beug H, Hennighausen L, Moriggl R, Sexl V. Clarifying the role of Stat5 in lymphoid development and Abelson-induced transformation. Blood. 2006; 107:4898-906.

9. Hoelbl A, Schuster C, Kovacic B, Zhu B, Wickre M, Hoelzl MA, Fajmann S, Grebien F, Warsch W, Stengl G, Hennighausen L, Poli V, Beug $\mathrm{H}$, et al. Stat5 is indispensable for the maintenance of bcr/abl-positive leukaemia. EMBO Mol Med. 2010; 2:98-110.

10. Walz C, Ahmed W, Lazarides K, Betancur M, Patel N, Hennighausen L, Zaleskas VM, Van Etten RA. Essential role for $\mathrm{Stat} 5 \mathrm{a} / \mathrm{b}$ in myeloproliferative neoplasms induced by BCR-ABL1 and JAK2(V617F) in mice. Blood. 2012; 119:3550-60.

11. Yan D, Hutchison RE, Mohi G. Critical requirement for Stat5 in a mouse model of polycythemia vera. Blood. 2012; 119:3539-49.

12. Choudhary C, Brandts C, Schwable J, Tickenbrock L, Sargin B, Ueker A, Böhmer FD, Berdel WE, Müller-Tidow C, Serve H. Activation mechanisms of STAT5 by oncogenic Flt3-ITD. Blood. 2007; 110:370-74.

13. Hantschel O, Warsch W, Eckelhart E, Kaupe I, Grebien F, Wagner KU, Superti-Furga G, Sexl V. BCR-ABL uncouples canonical JAK2-STAT5 signaling in chronic myeloid leukemia. Nat Chem Biol. 2012; 8:285-93. 
14. Irwin ME, Rivera-Del Valle N, Chandra J. Redox control of leukemia: from molecular mechanisms to therapeutic opportunities. Antioxid Redox Signal. 2013; 18:1349-83.

15. Naughton R, Quiney C, Turner SD, Cotter TG. Bcr-Ablmediated redox regulation of the PI3K/AKT pathway. Leukemia. 2009; 23:1432-40.

16. Bourgeais J, Gouilleux-Gruart V, Gouilleux F. Oxidative metabolism in cancer: A STAT affair? JAK-STAT. 2013; 2:e25764.

17. Thannickal VJ, Fanburg BL. Reactive oxygen species in cell signaling. Am J Physiol Lung Cell Mol Physiol. 2000; 279:L1005-28.

18. Hole PS, Darley RL, Tonks A. Do reactive oxygen species play a role in myeloid leukemias? Blood. 2011; 117:5816-26.

19. Koptyra M, Falinski R, Nowicki MO, Stoklosa T, Majsterek I, Nieborowska-Skorska M, Blasiak J, Skorski T. BCR/ABL kinase induces self-mutagenesis via reactive oxygen species to encode imatinib resistance. Blood. 2006; 108:319-27.

20. Penserga ET, Skorski T. Fusion tyrosine kinases: a result and cause of genomic instability. Oncogene. 2007; 26:11-20.

21. Sallmyr A, Fan J, Datta K, Kim KT, Grosu D, Shapiro P, Small D, Rassool F. Internal tandem duplication of FLT3 (FLT3/ITD) induces increased ROS production, DNA damage, and misrepair: implications for poor prognosis in AML. Blood. 2008; 111:3173-82.

22. Marty C, Lacout C, Droin N, Le Couédic JP, Ribrag V, Solary E, Vainchenker W, Villeval JL, Plo I. A role for reactive oxygen species in JAK2 V617F myeloproliferative neoplasm progression. Leukemia. 2013; 27:2187-95.

23. Sattler M, Verma S, Shrikhande G, Byrne $\mathrm{CH}$, Pride YB, Winkler T, Greenfield EA, Salgia R, Griffin JD. The $\mathrm{BCR} / \mathrm{ABL}$ tyrosine kinase induces production of reactive oxygen species in hematopoietic cells. J Biol Chem. 2000; 275:24273-78.

24. Kim JH, Chu SC, Gramlich JL, Pride YB, Babendreier E, Chauhan D, Salgia R, Podar K, Griffin JD, Sattler M. Activation of the PI3K/mTOR pathway by BCR-ABL contributes to increased production of reactive oxygen species. Blood. 2005; 105:1717-23.

25. Warsch W, Grundschober E, Berger A, Gille L, CernyReiterer S, Tigan AS, Hoelbl-Kovacic A, Valent P, Moriggl $\mathrm{R}$, Sexl V. STAT5 triggers BCR-ABL1 mutation by mediating ROS production in chronic myeloid leukaemia. Oncotarget. 2012; 3:1669-87.

26. Jayavelu AK, Müller JP, Bauer R, Böhmer SA, Lässig J, Cerny-Reiterer S, Sperr WR, Valent P, Maurer B, Moriggl R, Schröder K, Shah AM, Fischer M, et al. NOX4-driven ROS formation mediates PTP inactivation and cell transformation in FLT3ITD-positive AML cells. Leukemia. 2016; 30:473-83.

27. Casetti L, Martin-Lannerée S, Najjar I, Plo I, Augé S, Roy L, Chomel JC, Lauret E, Turhan AG, Dusanter-Fourt
I. Differential contributions of STAT5A and STAT5B to stress protection and tyrosine kinase inhibitor resistance of chronic myeloid leukemia stem/progenitor cells. Cancer Res. 2013; 73:2052-58.

28. Cholez E, Debuysscher V, Bourgeais J, Boudot C, Leprince J, Tron F, Brassart B, Regnier A, Bissac E, Pecnard E, Gouilleux F, Lassoued K, Gouilleux-Gruart V. Evidence for a protective role of the STAT5 transcription factor against oxidative stress in human leukemic pre-B cells. Leukemia. 2012; 26:2390-97.

29. Sillaber C, Gesbert F, Frank DA, Sattler M, Griffin JD. STAT5 activation contributes to growth and viability in Bcr/ Abl-transformed cells. Blood. 2000; 95:2118-25.

30. Ogasawara MA, Zhang $H$. Redox regulation and its emerging roles in stem cells and stem-like cancer cells. Antioxid Redox Signal. 2009; 11:1107-22.

31. Bauer G. Tumor cell-protective catalase as a novel target for rational therapeutic approaches based on specific intercellular ROS signaling. Anticancer Res. 2012; 32:2599-624.

32. Arai F, Hirao A, Suda T. Regulation of hematopoietic stem cells by the niche. Trends Cardiovasc Med. 2005; 15:75-79.

33. Ghaffari S. Oxidative stress in the regulation of normal and neoplastic hematopoiesis. Antioxid Redox Signal. 2008; 10:1923-40.

34. Lane SW, Scadden DT, Gilliland DG. The leukemic stem cell niche: current concepts and therapeutic opportunities. Blood. 2009; 114:1150-57.

35. Urao N, Ushio-Fukai M. Redox regulation of stem/ progenitor cells and bone marrow niche. Free Radic Biol Med. 2013; 54:26-39.

36. Roecklein BA, Torok-Storb B. Functionally distinct human marrow stromal cell lines immortalized by transduction with the human papilloma virus E6/E7 genes. Blood. 1995; 85:997-1005.

37. Moriggl R, Gouilleux-Gruart V, Jähne R, Berchtold S, Gartmann C, Liu X, Hennighausen L, Sotiropoulos A, Groner B, Gouilleux F. Deletion of the carboxyl-terminal transactivation domain of MGF-Stat5 results in sustained DNA binding and a dominant negative phenotype. Mol Cell Biol. 1996; 16:5691-700.

38. Harir N, Pecquet C, Kerenyi M, Sonneck K, Kovacic B, Nyga R, Brevet M, Dhennin I, Gouilleux-Gruart V, Beug H, Valent P, Lassoued K, Moriggl R, Gouilleux F. Constitutive activation of Stat5 promotes its cytoplasmic localization and association with PI3-kinase in myeloid leukemias. Blood. 2007; 109:1678-86.

39. Fernandes AP, Holmgren A. Glutaredoxins: glutathionedependent redox enzymes with functions far beyond a simple thioredoxin backup system. Antioxid Redox Signal. 2004; 6:63-74.

40. Pineda-Molina E, Klatt P, Vázquez J, Marina A, García de Lacoba M, Pérez-Sala D, Lamas S. Glutathionylation of the p50 subunit of NF-kappaB: a mechanism for 
redox-induced inhibition of DNA binding. Biochemistry. 2001; 40:14134-42.

41. Xie Y, Kole S, Precht P, Pazin MJ, Bernier M. S-glutathionylation impairs signal transducer and activator of transcription 3 activation and signaling. Endocrinology. 2009; 150:1122-31.

42. Nieborowska-Skorska M, Kopinski PK, Ray R, Hoser G, Ngaba D, Flis S, Cramer K, Reddy MM, Koptyra M, Penserga T, Glodkowska-Mrowka E, Bolton E, Holyoake TL, et al. Rac2-MRC-cIII-generated ROS cause genomic instability in chronic myeloid leukemia stem cells and primitive progenitors. Blood. 2012; 119:4253-63.

43. Brown MR, Miller FJ Jr, Li WG, Ellingson AN, Mozena JD, Chatterjee P, Engelhardt JF, Zwacka RM, Oberley LW, Fang $X$, Spector AA, Weintraub NL. Overexpression of human catalase inhibits proliferation and promotes apoptosis in vascular smooth muscle cells. Circ Res. 1999; 85:524-33.

44. Gupta R, Karpatkin S, Basch RS. Hematopoiesis and stem cell renewal in long-term bone marrow cultures containing catalase. Blood. 2006; 107:1837-46.

45. Wang Z, Li G, Tse W, Bunting KD. Conditional deletion of STAT5 in adult mouse hematopoietic stem cells causes loss of quiescence and permits efficient nonablative stem cell replacement. Blood. 2009; 113:4856-65.

46. Tam WF, Hähnel PS, Schüler A, Lee BH, Okabe R, Zhu N, Pante SV, Raffel G, Mercher T, Wernig G, Bockamp E, Sasca D, Kreft A, et al. STAT5 is crucial to maintain leukemic stem cells in acute myelogenous leukemias induced by MOZ-TIF2. Cancer Res. 2013; 73:373-84.

47. Schepers H, Wierenga AT, Vellenga E, Schuringa JJ. STAT5-mediated self-renewal of normal hematopoietic and leukemic stem cells. JAK-STAT. 2012; 1:13-22.

48. Santos SC, Lacronique V, Bouchaert I, Monni R, Bernard O, Gisselbrecht S, Gouilleux F. Constitutively active STAT5 variants induce growth and survival of hematopoietic cells through a PI 3-kinase/Akt dependent pathway. Oncogene. 2001; 20:2080-90.

49. Vignon C, Debeissat C, Georget MT, Bouscary D, Gyan E, Rosset P, Herault O. Flow cytometric quantification of all phases of the cell cycle and apoptosis in a two-color fluorescence plot. PLoS One. 2013; 8:e68425.

50. Livak KJ, Schmittgen TD. Analysis of relative gene expression data using real-time quantitative PCR and the 2(-Delta Delta C(T)) Method. Methods. 2001; 25:402-08. 